4. Иванов А.С. Методика статистической обработки составов типоморфных минералов кимберлитовых трубок в Якутии. Прикладная Геохимия. Вып. 5. Москва. 2005.

5. Иванов А.С. Методика вычисления минеральных парастерезисов в кимберлитах. Труды XIII Всероссийской (с международным участием) научной школы «Математические исследования в естественных науках». КНЦ РАН Апатиты, 2016.С. 147-151.

6. Иванов А.С. Статистическое сравнение составов минералов-спутников алмазов на разных уровнях вероятности и его прогнозно-поисковое значение // Вопросы методики прогнозирования и поисков месторождений полезных ископаемых. ЯНИГП ЦНИГРИ АК «АЛРОСА». 2004. С. 247-253.

7. Квасница В.Н., Мацюк С.С., Вуйко В.И. О парагенетической связи алмаз - гранат // Минералогический журнал. 1984. № 5. С. 23-34.

8. Соболев Н.В. О минералогических критериях алмазоносности кимберлитов // Геология и геофизика 1971. №3. С. 70-80.

9. Dawson J.B., Stephens W.E. Statistical classification of garnets from kimberlites and xenoliths. J. Geol. 1975. V. 83. № 5. P. 589-607.

\title{
ВОЛНОВАЯ ГЕОДИНАМИКА И ПЛОЩАДНЫЕ ГЕОХИМИЧЕСКИЕ ВАРИАЦИИ
}

\section{Ильченко В.Л. ${ }^{1}$, Сенчина Н.П. ${ }^{2}$}

${ }^{1}$ Геологический институт КНЦ РАН, Апатиты, vadim@geoksc.apatity.ru

${ }^{2}$ Санкт-Петербургский горный университет, Санкт-Петербург,

n_senchina@inbox.ru

\section{Аннотация}

На основе волновой геодинамики рассмотрена природа тектонических нарушений в породах древнего кристаллического фундамента - в связи с развитием рельефа и площадным распределением геохимических аномалий на поверхности. Результаты проведённого исследования показали возможную связь геоморфологических особенностей объекта с его геохимическими характеристиками (площадными вариациями концентраций химических элементов).

\section{Summary}

Nature of tectonic disturbances in the ancient crystalline basement rocks with comparison of the relief development and of the geochemical anomalies area distribution on the surface were considered on the basis of wave geodynamics. The study results show possible relationship of the object's geomorphological features and its geochemical characteristics (area variations of chemical elements concentrations).

\section{Введение}

Одним из важнейших методов поисковой геологии является геохимическая съёмка, позволяющая находить месторождения полезных ископаемых в 
породах кристаллического фундамента, перекрытых многометровыми толщами отложений. Наилучших результатов, в настоящее время (когда геологами исследована почти вся земная поверхность), можно достичь путём комплексирования разных поисковых методов [16]. Месторождения маркируются на поверхности геохимическими аномалиями, сформированными в ходе перемещения с глубины химических элементов в составе струйных ореолов рассеяния различного происхождения $[19,20]$. Оптимальные пути для продвижения ореолов - ослабленные зоны - системы тектонических нарушений (трещин) в перекрывающих рыхлых толщах. Эти ослабленные зоны часто развиваются на продолжении разломных зон в породах фундамента, что должно находить отражение также в геоморфологии, где гармонический анализ можно использовать в изучении временных изменений рельефа и пространственной периодичности земной поверхности [17]. Волнообразный характер в распределении площадных вариаций показателя упругой анизотропии пород (в «противофазе» с высотами точек отбора образцов, в том числе) наблюдался ранее на ряде объектов Мурманской области $[13,9,10]$.

\section{Системы разломных зон на земной поверхности}

Более 40 лет назад, сотрудниками СЗТГУ (Ленинград), на Кольском полуострове были проведены исследования пространственного распределения массивов центрального типа, которые образуют единую средневерхнепалеозойскую формацию, чей состав закономерно меняется от ультраосновных щелочных пород до нефелиновых и щелочных сиенитов [3]. В итоге установлена приуроченность всех массивов к точкам пересечения радиальных разломов с кольцевыми разломами разного радиуса с центрами в пределах Хибинского массива; размеры радиусов $(60,85,120,170$ км) образуют геометрическую прогрессию по закону: $R_{n}=\sqrt{2} R_{n-1}(R-$ радиус $n$-го кольца, $n$ - его порядковый номер). Эта формула позволила наметить положение ещё нескольких кольцевых разломов [3]. Аналогичное расположение таких кольцевых разломов обнаружено в морфоструктурах ТиманоУральского региона, а также на снимках поверхностей Марса и Луны, что говорит о его фундаментальном характере. Помимо «главной» системы концентрических нарушений с центром в районе Хибин, были установлены кольцевые системы второго порядка, фиксируемые вокруг более мелких интрузий, с выводом, что такие системы характерны для всех массивов центрального типа [3].

Хибинский массив - это щелочной интрузивный комплекс палеозойского возраста в обрамлении докембрийских метаморфических пород фундамента. Этот массив имеет изометричную (округлую в плане) форму и платообразную поверхность, глубоко (до 800 м) расчленённую ледниковоэрозионными долинами на отдельные фрагменты [18]. Явный геоморфологический контраст (крутые склоны) на геологической границе массива предполагает, что хибинские породы существенно отличаются по физическим свойствам (прочность, плотность, упругость и др.) от вмещающих пород. 
Формально, Хибинский массив представляет собой крупную контрастную неоднородность, под влиянием которой сформировалась система кольцевых разломов [3] и, видимо, развитие подобных систем можно ожидать в сходной по геологическим условиям ситуации. Аналогом такой неоднородности является горная выработка, полости которой резко контрастируют по физическим свойствам с вмещающими породами массива; эта аналогия подкрепляется «явлением зональной дезинтеграции горных пород вокруг глубоких подземных выработок» [14].

\section{Зональная дезинтеграция пород вокруг глубоких выработок}

Суть явления: массив горных пород вокруг пустот горных выработок (на большой глубине) разрушается пошагово-зонально. Разрушение начинается уже на контуре выработки (зона № 0), затем, на определенном расстоянии от неё возникает зона №1, где все трещины ориентированы параллельно контуру выработки; так же «квантообразно» (порционно), образуются прочие зоны разрушения. Эта зональность описывается математической закономерностью: последовательность средних значений радиусов зон разрушения образует геометрическую прогрессию с основанием $\sqrt{2}$. Авторы (открыватели) этого явления считают причиной выявленной закономерности «квантованное распределение геомеханической энергии с коэффициентом подобия, $(\sqrt{ } 2)^{n}(\mathrm{n}-$ все целые числа)» [14]. Дискуссии вокруг природы «эффекта квантования» продолжаются, адекватная физическая модель, как и теория явления, не созданы и ни одна из гипотез о его природе (которые были предложены) также не верифицирована [6]. Между тем, механизм развития зональной дезинтеграции пород в окрестностях горных выработок прекрасно объясняется волновой геодинамикой [12], использующей некоторые позиции из спектральной сейсморазведки А.Г. Гликмана [6] и ритмодинамики Ю.Н. Иванова [8].

\section{Волновая геодинамика}

Согласно работам А.Г. Гликмана [6], все геологические объекты в составе литосферы следует рассматривать как колебательные системы, которые могут способствовать появлению и взаимодействию систем стоячих волн. Конфигурация и число таких колебательных систем зависит от формы объекта - источника колебаний. Например, возбуждение колебаний в теле цилиндрической формы (пьезокерамический диск) приводит к тому, что это тело начинает «излучать» две упругих волны: первая волна - по высоте $\left(\lambda_{1}=|h|\right)$, вторая - по диаметру $\left(\lambda_{2}=|d|\right)$ диска [6]. Суммарный сигнал от этих двух волн показан на рис.1,a; в спектре сигнала проявляется два пика (рис. 1,6$)$. Поскольку геологическая среда имеет как проводящие, так и отражающие свойства, вокруг источников колебаний - контрастных неоднородностей - неизбежно возникают сложные системы стоячих волн.

Из «Ритмодинамики» Ю.Н. Иванова известно [8], что в природе существует лишь три вида идеально устойчивых волновых систем минимально- 

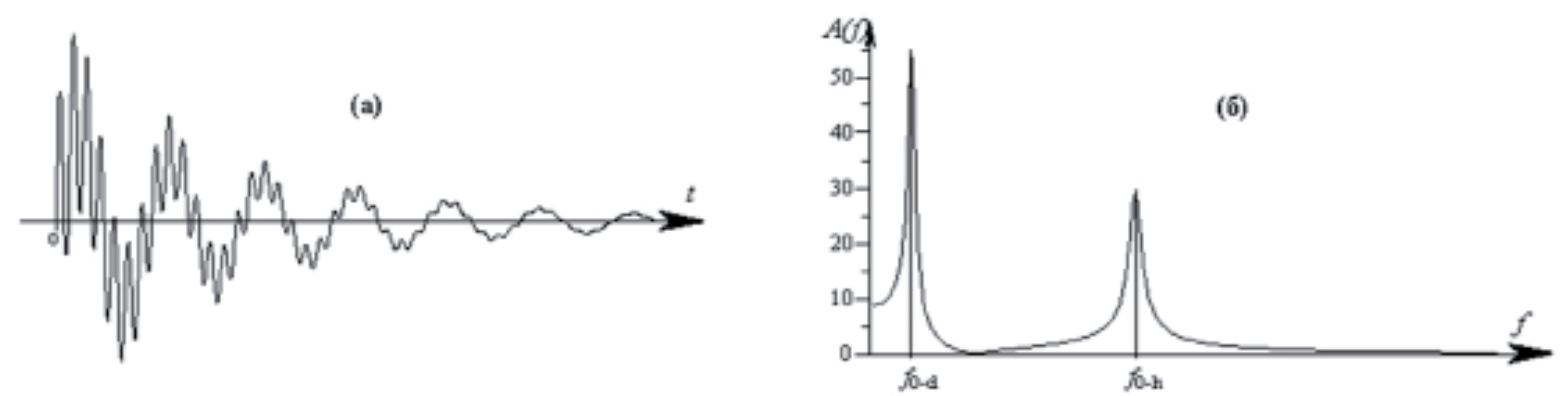

Рис. 1. Колебание пьезокерамического (а) диска и его спектр (б), из [5].

го размера: два осциллятора и стоячая волна между ними; три осциллятора, образующие равносторонний треугольник с длиной стороны, равной длине стоячей волны $\lambda$ и, наконец, четыре осциллятора в форме равностороннего тетраэдра (длина ребра равна длине волны $\lambda$ ). В прочих правильных многоугольниках, если их превратить в осцилляторы, сразу возникают перекрёстные нецелочисленные связи в виде тех же стоячих волн. Эти нецелочисленные стоячие волны уменьшают устойчивость систем [8].

Например, в квадрате с длиной стороны $\lambda_{\text {ст }}=1$, длина диагонали $\lambda_{d}=\lambda_{\text {ст }} \sqrt{2}$. Величину $\sqrt{2}$ дает теорема Пифагора для равнобедренного прямоугольного треугольника $\left(a^{2}+b^{2}=c^{2}\right.$, если $\left.a=b, c=\sqrt{ } 2\right)$; так же определяется длина диагонали контура горной выработки с квадратным сечением (если контур не «строго квадратный», а, скажем, прямоугольный, множитель $\sqrt{ } 2$ никуда не исчезнет; диагональ любого прямоугольника, вписанного в окружность, равна диаметру этой окружности). С превращением контура в осциллятор (приливной волной, например [5]), его границы начинают «излучать» во вмещающее пространство колебания, длина волны $\lambda$ которых пропорциональна размерам источника. В горных породах эти колебания преобразуются в стоячие волны длиной $\lambda / 2$ (расстояние до «ближайшей» узловой точки и длина стоячей волны). Колебания продольной стоячей волны «отжимают» из пучности часть напряжений к узловым точкам, превращая их в концентраторы избыточно высоких напряжений, где создаются дополнительные предпосылки к разрушению пород и формированию зон трещиноватости [5]. Множество узлов на расстоянии $\lambda / 2$ от границы осциллятора образует сетку, повторяющую его форму. Переизбыток напряжений в узлах ведёт к разрушению пород по этой сетке с появлением новой осциллирующей поверхности и одновременным её превращением в новый колебательный контур соответственного размера, после чего цикл повторяется. Так обеспечивается шаговый ритм в системной зональности. При развитии зон дезинтеграции пород вокруг контура выработки с квадратным сечением «работают» две колебательные системы: контурная - когда стоячие волны создаются колебаниями плоскопараллельных сторон квадрата: $\lambda_{n}=\lambda_{0}(2)^{\mathrm{n}}$ и диагональная, когда стоячие волны формируются на продолжении диагоналей квадрата $\lambda_{n}=\lambda_{0}(\sqrt{ } 2)^{\mathrm{n}}[6]$. 
Радиусы вписанной в правильный многоугольник и описанной вокруг этой фигуры окружностей связаны строгими соотношениями [4]. Так, для квадрата: $R / r=\sqrt{ } 2$ ( $R$ - радиус описанной окружности, $r-$ вписанной). Формула $R / r=\sqrt{2}$ ничем не отличается от закона развития системы кольцевых разломов, обнаруженной вокруг Хибин [2]: $R_{n}=\sqrt{2} R_{\mathrm{n}-1}$.

Принимая средний радиус Хибинского массива $\left(R_{0}\right)$ за «точку отсчета», перепишем закономерность $\left(R_{n}=\sqrt{ }(2) R_{n-1}\right)$ [3] так, чтобы придать ей более «законченный» вид: $R_{n}=R_{0}(\sqrt{2})^{n}$. Теперь закон развития системы кольцевых разломов вокруг массива не отличается от $\lambda_{n}=\lambda_{0}(\sqrt{ } 2)^{n}-$ для развития зональной дезинтеграции пород вокруг горных выработок по диагональной компоненте волновой системы контура выработки с квадратным сечением [6].

Вернемся теперь к концентрической системе разломов кольцевой формы с центрами в границах Хибинского массива, чья последовательность радиусов $(60,85,120,170$ км) образует геометрическую прогрессию по закону: $R_{n}=\sqrt{2} R_{n-1}\left(R_{n}-\right.$ радиус $n$-го кольца, $n-$ его порядковый номер в серии концентрических колец). Как сказано в [3], эта формула позволила наметить положение ещё нескольких кольцевых разломов; если считать от $=170$ км, последовательно получим радиусы 240, 340 км (и т.д.). Так как в пределах массива «радиальные разломы подчеркиваются ориентировкой озер и прослеживаются по геологическим и геоморфологическим данным» [3], радиусы этих разломов могут быть вычислены пересчётом в «обратную» сторону - по формуле $R_{n-1}=R_{n} \sqrt{2}$ (от $R_{n}=60$ км), что даёт продолжение прогрессии: $42.4,30,21.2$ км (и т.д.), причём значение 42.4 км совпадает со средним диаметром Хибинского массива, а 21.2 км, соответственно, - его радиус. Два последних радиуса (30 и 21.2 км) близки к размерам кольцевых нарушений в Хибинском массиве - «радиусом 20-35 км, отмеченным зонами милонитизации шириной до 50 м, проявлениями щелочного магматизма и элементами рельефа» [3].

Представленная выше «картина» выглядит неполной без механизма тектонического расслоения земной оболочки в ритме затухающей колебательной системы с динамикой стоячей волны, описываемого законом затухания звука в натянутой струне: $\lambda_{n}=\lambda_{0} / 2^{\mathrm{n}}$, где $\lambda_{n}-$ длина $n$-й моды (мощность $n$-го элемента расслоения), $\lambda_{0}$ - длина струны (в нашем случае, мощность земной коры - колебательной системы). Тектоническое расслоение пород земной оболочки вызывается развитием в ней иерархичной и ритмично построенной системы субгоризонтальных зон трещиноватости, пространственно совпадающих с множеством узловых точек стоячей волны - концентраторов избыточно высоких напряжений [11]. При этом мощность колебательной системы $\lambda_{0}$ можно вычислить из расстояния $\lambda_{n}$ между соседними трещиноватыми зонами, по формуле: $\lambda_{0}=\lambda_{n} 2^{n}$, если знать номер моды расслоения.

Все приведенные факты о закономерности развития разломов описываются степенной функцией и образуют иерархические фрактальные структуры. Значит, процесс развития ландшафтов (рельефа) подчиняется теории 
самоорганизованной критичности [2]. Элементы тектоники также проявляются в результатах геохимических работ как положительные аномалии подвижных форм нахождения некоторых химических элементов [1].

\section{Геохимическая съёмка}

В пределах Мончегорского горно-промышленного района Мурманской области, в 2001 году, с целью изучения подвижных (вторично-закрепленных) форм нахождения химических элементов термомагнитным геохимическим методом - ТМГМ [5], с шагом опробования $\approx 70$ м был исследован профиль Волчьи тундры - Колозеро длиной 43.5 пог. км (рис. 2) [15].

Термомагнитный геохимический метод основан на исследовании закономерностей распределения химических элементов, связанных с гидроксидами железа и марганца в почвах (или с железо- и марганецсодержащими минералами в горных породах). Научной основой ТМГМ является теория о дальней миграции химических элементов в легкоподвижных формах нахождения с последующим закреплением и накоплением на путях транспортировки и вблизи дневной поверхности при взаимодействии их с железо- и марганецсодержащими минералами. В состав работ ТМГМ входят: полевой отбор проб, их магнетизирующий обжиг с выделением термомагнитной фракции; ее анализ на содержание элементов-индикаторов и измерение

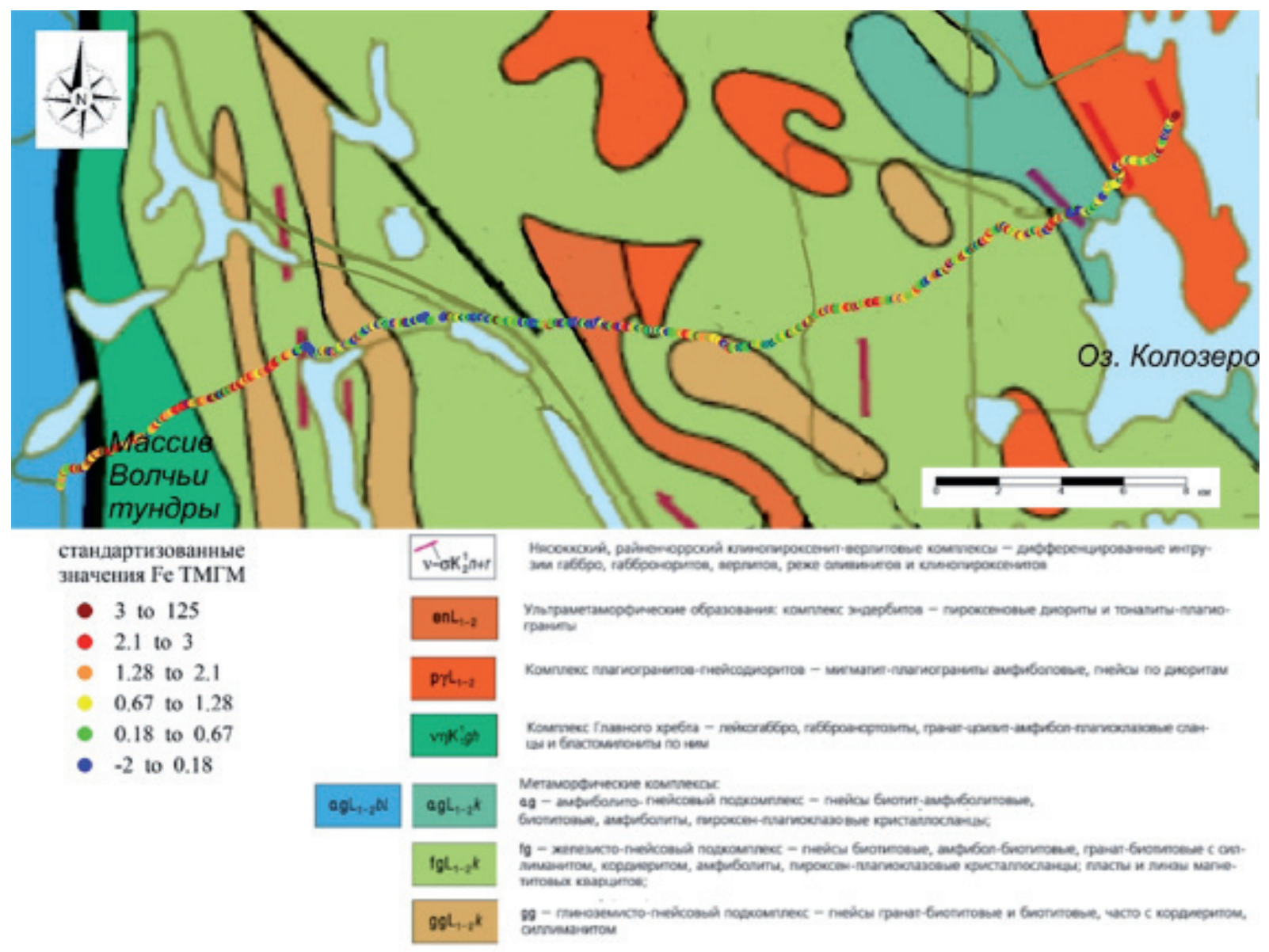

Рис. 2. Геологическая карта участка с распределением железа (ТМГМ) по профилю Волчьи тундры - Колозеро. 
магнитной восприимчивости пробы до и после обжига [5]. При этом аномально повышенные концентрации металлов, по данным геоэлектрохимии, как правило, приурочены к проекции концевых частей рудных тел на дневную поверхность. Аномалиями геоэлектрохимических методов выделяются не только сами рудные объекты, но и сопряженные с ними структурнотектонические элементы земной коры, в частности зоны разломов. Обычно наложенные ореолы, связанные с разломами, невелики по ширине и полосой трассируют разлом. Наиболее значимыми химическими элементами при прослеживании разломов являются железо, марганец, а также некоторые из редких и рассеянных элементов (литий, цезий и пр.) [5].

«Мончегорский рудный район расположен в центральной части Кольского полуострова, является частью раннепротерозойского ПеченгскоВарзугского рифтогенного пояса. Ведущую роль в формировании его структурного облика играют различно ориентированные глубинные разломы и массивы магматических пород с возрастом 2.5-2.4 млрд. лет. Среди разломов наиболее важными являются системы северо-западного простирания, которые могут трактоваться как продолжение осевых (Сейдозерский и, возможно, Кислогубский) и краевых (Кашкозерский, Волчьеозерско-Мончегубский, Южно-Чунатундровский) разломов Имандра-Варзугской зоны. Осевые разломы являлись главными зонами поступления продуктов магмогенерации.

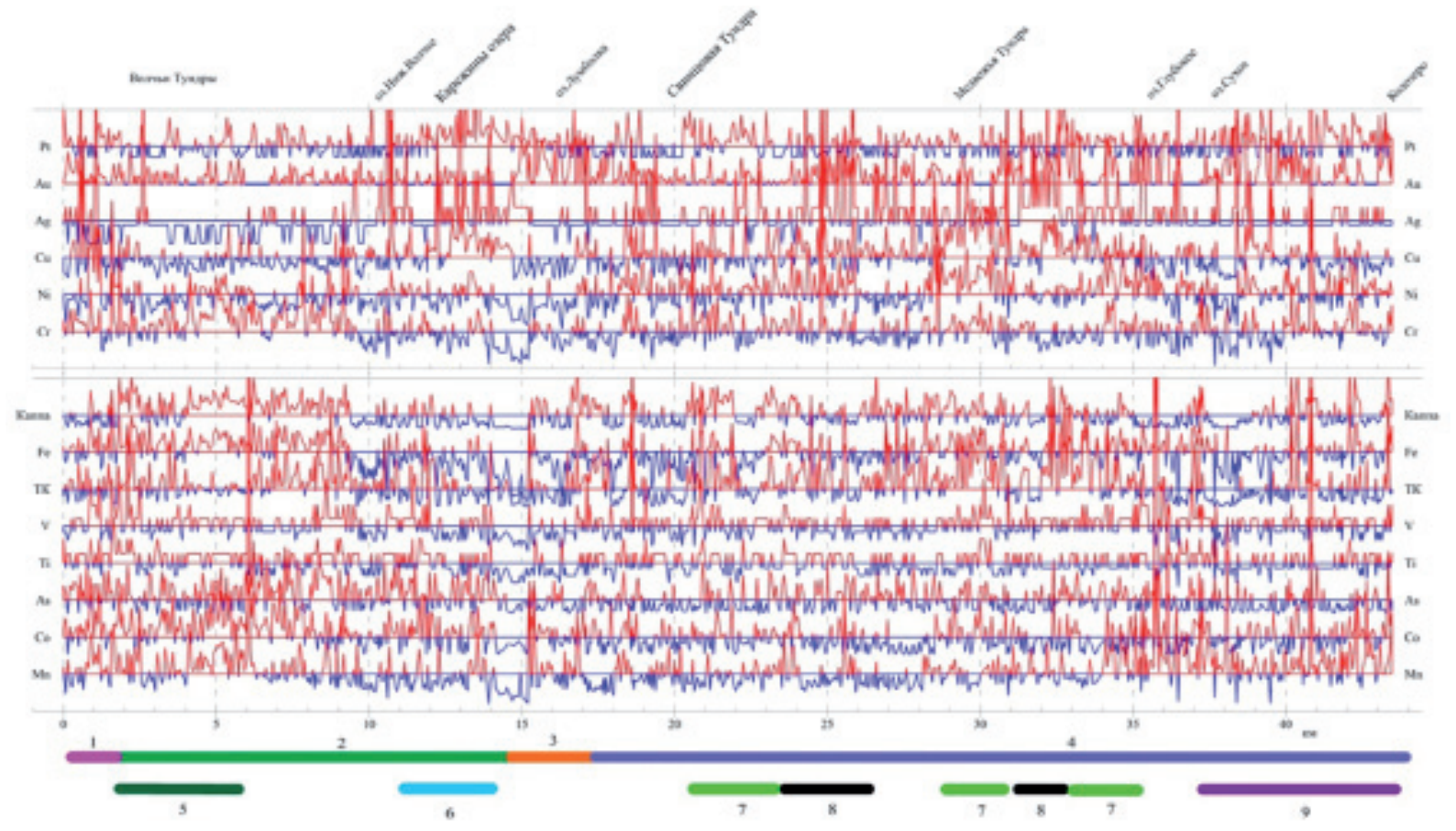

Рис. 3. Графики концентрации элементов по профилю. Оси графиков проведень через 3 стандартных отклонения. Структуры I-II порядка: 1 - зона сочленения с Беломорским геоблоком; 2 - Волчьетундровский блок; 3 - зона Кашкозерского глубинного разлома; 4 - Колозерский блок. Структуры III порядка: Волчьетундровский массив. Структуры IV порядка: 6 - полоса выходов интрузий пироксенитверлитового комплекса; 7 - зоны развития даек основного-ульстраосновного состава; 8 - зоны развития тел железистых кварциттов; 9 - полоса выходов Колозерских интрузий. 
Поперечные системы нарушений (Куцкольская, Вайкисозерская, Оленегорская) представляют собой ступенчатые сбросы и сбросо-сдвиги, являясь трансформными. Они контролируют размещение крупных магматических масс, создавая благоприятные условия для их бокового внедрения из осевых зон. Сбросы и сбросо-сдвиги субмеридионального простирания (Большой Меридиональный, Меридиональный, Лампрофировый, Восточный и др.) являются более поздними и формировались в условиях растяжения. Они контролируют размещение даек и жил внутри массивов и за их пределами» [15].

Рассмотрим графики концентрации элементов (рис. 3). Общий вид этих графиков позволяет выделить зоны, связанные с повышенной перспективностью их на те или иные элементы, приуроченные к интрузиям или другим геологическим разностям. Кроме того, на этих графиках хорошо заметна квазипериодическая составляющая. Предположительно, эта квазипериодичность может быть связана с «регулярными» разломами, чьё развитие происходило по волновому «сценарию», как и формирование кольцевых и радиальных разломных зон вокруг Хибинского массива [3].

На основании предположения о существовании квазипериодической составляющей результаты геоэлектрохимии рассмотрены с точки зрения волновых процессов, для чего были построены «спектры», где по горизон-

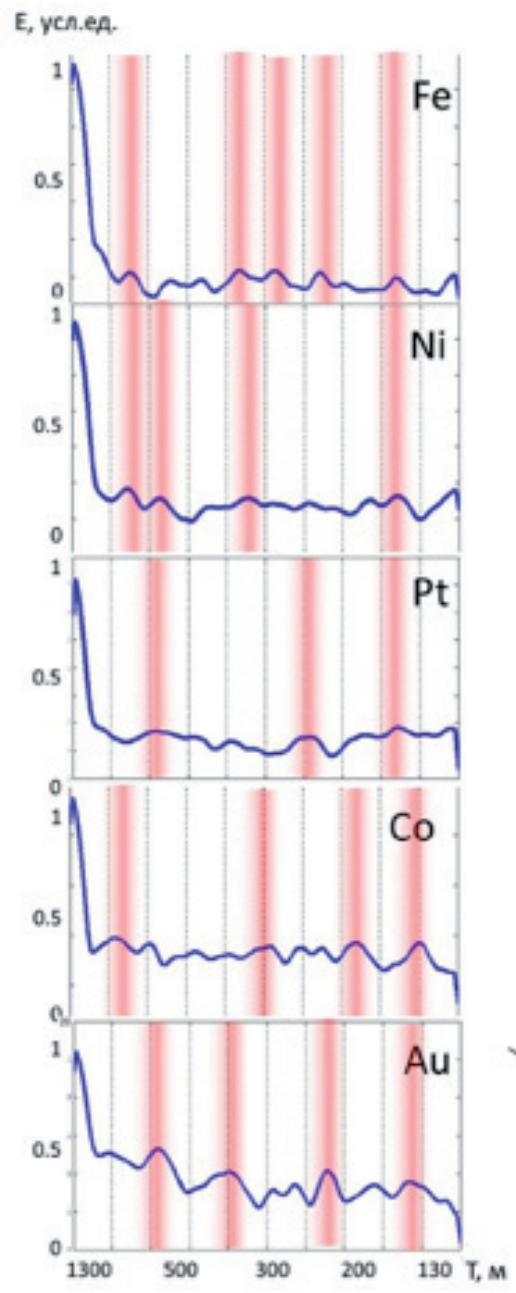

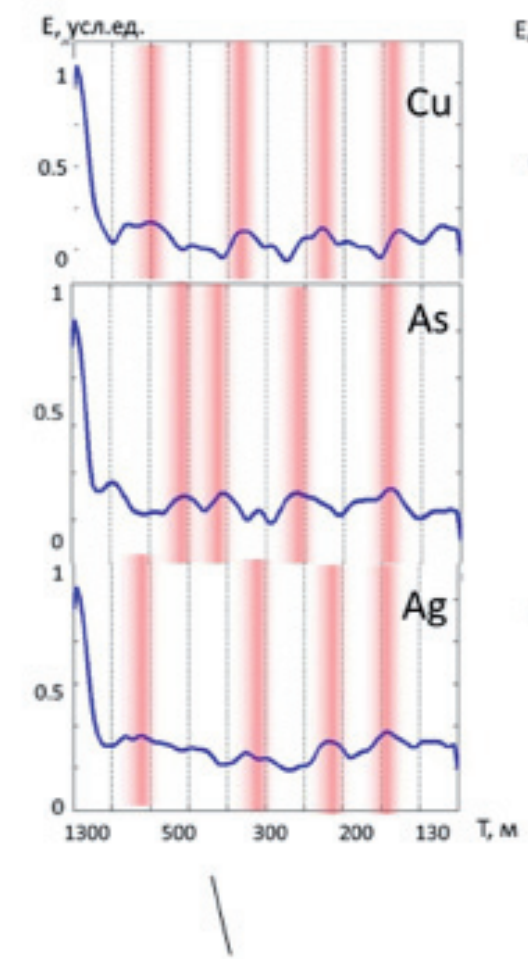

Халькофильные элементы

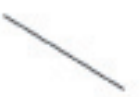

Сидерофильные элементы

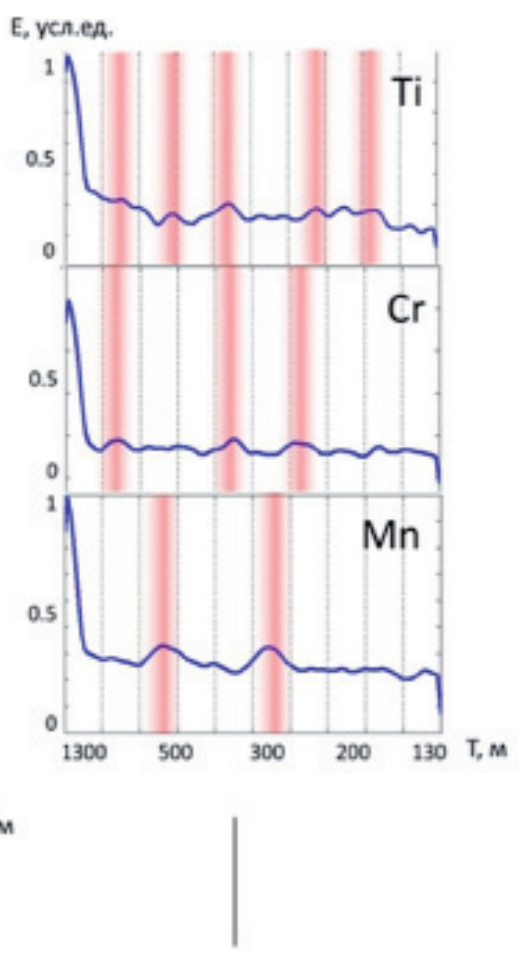

Литофильные элементы

Рис. 4. Спектры распределения химических элементов по профилю. 
тальной оси откладывается пространственный период (T, м), по вертикальной - вклад данной частотной компоненты в вариации геохимических данных (Е, усл. ед.). Пики на «спектрах» отмечены цветом (рис. 4). «Спектры» сгруппированы по геохимическим особенностям элементов. Любопытно совпадение пиков распределений железа, никеля, платины при значении «периода» около 150 м, совпадение пиков распределения меди, мышьяка, серебра при Т = 180 м. Данные факты и другие соответствия между «спектрами» наводят на мысль о наличии скрытой закономерности и взаимосвязи рассматриваемых процессов.

Как известно, более проницаемые для струйных ореолов рассеяния породы локализуются в ослабленных зонах, отличаются высокими показателями упругой анизотропии и трещиноватости, что делает их менее стойкими к процессам выветривания [9]. Формирование рельефа прямо связано с избирательностью процессов выветривания, когда в первую очередь разрушаются менее стойкие породы с развитием отрицательных форм рельефа (и наоборот). Отсюда идея - установить связь между геохимическими аномалиями на земной поверхности и геоморфологией.

«При ударном воздействии сразу на несколько колебательных систем временное изображение результирующего сигнала-отклика (рис. 5) обычно имеет столь сложную форму, что изучение его имеет смысл только на спектральной плоскости» [6].

При анализе участка, трассируемого геохимическим профилем (рис. 6), было выделено $\approx 12$ предположительно кольцевых объектов. Приблизительные границы «колец» проводились через их «фрагменты» дугообразной формы, которые образуют положительные формы рельефа. Примечательно, что примерно по столько же - в среднем - 10 (8-12) «пиков»

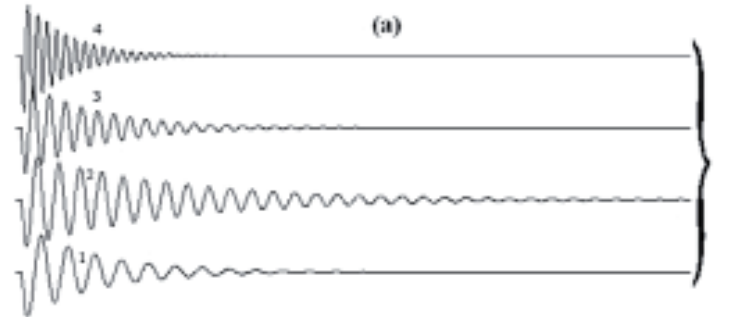

(6)

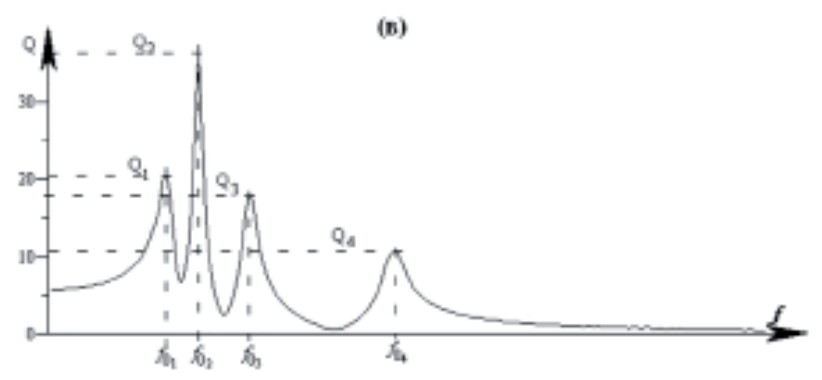

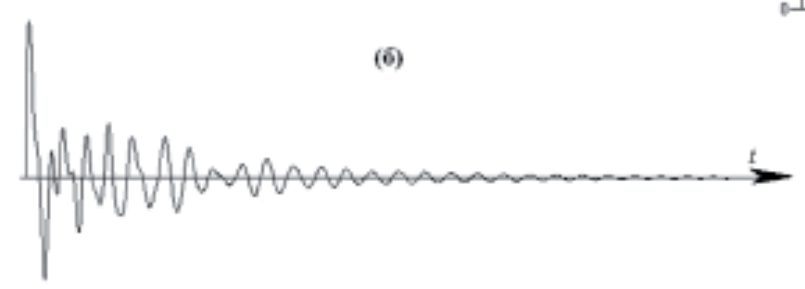

Рис. 5. Воздействие сразу на 4 колебательные системы (а) вызывает результируюший сигнал-отклик (б); спектральное изображение суммарного сигнала (в) содержит информацию о собственных частотах возбуждаемых систем, а также об их добротностях, и от изменения фазовых соотночений между его составляющими не зависит [6]. 
можно насчитать в спектрах (рис. 4) - т. е. примерно по одному «пику» на каждый кольцевой объект. Если воспринимать каждый такой спектральный «пик» как результат влияния автономного источника колебаний (рис. 5) [6], можно прийти к выводу о возможной динамической (волновой) причастности выделенных (рис. 6) кольцевых объектов к развитию вокруг них сложной системы тектонических нарушений и проницаемых ослабленных зон в перекрывающих толщах осадков. Предметом будущих исследований является окончательное вычисление параметров системы кольцевых нарушений.

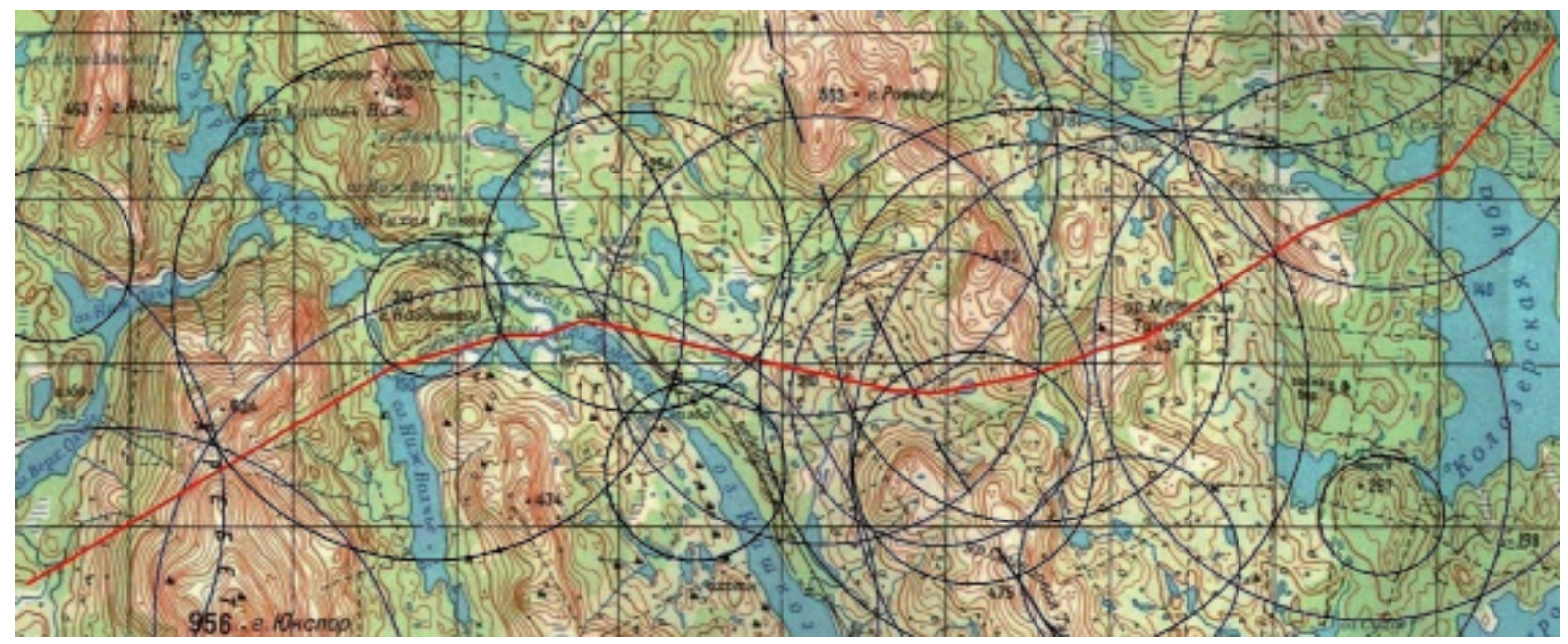

Рис. 6. Физическая карта района; геохимический профиль - красная линия. Чёрные окружности - возможные граниџы объектов кольиевой формы. Масштаб: 1 клетка $=5 \mathrm{\kappa м}$.

\section{Выводы}

Из результатов проведённого исследования следует, что предположение о возможной связи геоморфологических особенностей объекта с его геохимическими характеристиками (площадными вариациями концентраций химических элементов), в принципе, подтвердилось. Для однозначного установления указанной взаимосвязи необходимо исследовать максимально простой по строению объект с относительно ярко проявленными системами тектонических нарушений. Обнаружить такой объект в полигенной геологической среде - большая трудность. Однако, подтверждение гипотезы откроет ряд новых возможностей для прогнозирования месторождений полезных ископаемых, для утончения оптимального шага геохимических наблюдений.

Кроме того, результаты данной работы можно применять в инженерноэкологических исследованиях - путём геоморфологического анализа участков земной поверхности (по физическим картам и аэрофотоснимкам) - с целью выявления неоднородностей тектонической природы (разломных зон и т.п.) в условиях плохой обнажённости. 


\section{Список литературы}

1. Алексеев С.Г., Вешев С.А., Ворошилов Н.А., Путиков О.Ф., Савицкий А.П., Штокаленко М.Б. Технология работ и интерпретации данных геоэлектрохимических методов на рудных объектах (методические рекомендации) / ФГУ НПП «Геологоразведка». Санкт-Петербург. 2005. 60 с.

2. Бак П. Как работает природа: Теория самоорганизованной критичности. М.: УРСС. Книжный дом «ЛИБРОКОМ». 2013. 276 с.

3. Беляев К.Д., Увадьев Л.И., Шульга Т.Ф. Закономерности размещения массивов центрального типа Кольского полуострова // ДАН. 1976. Т. 226. №1. С. 163-165.

4. Бронштейн И.Н., Семендяев К.А. Справочник по математике для инженеров и учащихся втузов. 13-е изд., испр. М.: Наука. 1986. 544 с.

5. Ворошилов Н.А., Ворошилова Л.Н. Применение термомагнитного геохимического метода (ТМГМ) при поисках рудных месторождений / Методы интерпретации результатов литохимических поисков. М.: Наука, 1987. C. $135-141$.

6. Гликман А.Г. Теория и практика спектральной сейсморазведки // http://www.newgeophys.spb.ru/ru/book2/

7. Зональная дезинтеграция горных пород// http://www.ru.wikipedia.org/wiki/

8. Иванов Ю.Н. Ритмодинамика. М.: ИАЦ Энергия. 2007. 215 с.

9. Ильченко В.Л. О результатах изучения анизотропии упругих свойств горных пород из зоны Лучломпольского разлома (Печенгский район, Кольский полуостров) // Физика Земли. 2009. №3. С. 64-72.

10. Ильченко В.Л. О вариациях плотности и анизотропии упругих свойств архейских пород в приповерхностном залегании (на примере ЦентральноКольского мегаблока, Балтийский щит) // Геоэкология. Инженерная геология. Гидрогеология. Геокриология. 2010. №1. С. 73-79.

11. Ильченко В. Приливные волны и динамическая эволюция Земли. Саарбрюккен. LAMBERT Academic Publishing. 2013. 292 c.

12. Ильченко В.Л., Медведева С.Г. О посттехногенных нарушениях в массиве горных пород // Геоэкология. Инженерная геология. Гидрогеология. Геокриология. 2013. №5. С. 454-458.

13. Ильченко В.Л., Самигулин Р.Р., Каулина Т.В. Вариации упругих свойств пород урановых рудопроявлений (рудопроявление Береговое, Лицевский рудный район, Кольский регион) // Труды Ферсмановской научной сессии ГИ КНЦ РАН. 2017. № 14. С. 103-104.

14. Опарин В.Н., Тапсиев А.П., Чанышев А.И. 1-я Китайско-Российская научная конференция «Нелинейные геомеханико-геодинамические процессы при отработке полезных ископаемых на больших глубинах» // ФТПРПИ, №3. 2011. С.111-115.

15. Проведение глубинных геофизических исследований в Мончегорском районе, пояснительная записка, ВИРГ-Рудгеофизика. СПб. 2003. 149 с. 
16. Сенчина Н.П. Поиски коренной платиноидной минерализации путём изучения естественных электрических полей и ореолов рассеяния подвижных форм нахождения химических элементов / Автореф. дисс. к.г.-м.н. 2017. С.-Пб. Горный университет. Санкт-Петербург. 22 с.

17. Харченко С.В. К вопросу о применении гармонического анализа при количественной характеристике рельефа //Геоморфология. 2017. №2. С.14-24. 18. Хибинский щелочной массив / Материалы по геологии и полезным ископаемым Северо-Запада РСФСР. Л.: «Недра», 1972. 176 с.

19. Штокаленко М.Б., Путиков О.Ф., Алексеев С.Г., Вешев С.А., Ворошилов Н.А. Оценка параметров струйной миграции по ширине ореола вторично закрепленных форм химических элементов // Геофизика. 2006. № 4. С. 55-60.

20. Штокаленко М.Б., Алексеев С.Г., Вешев С.А., Ворошилов Н.А., Маргович Е.Г., Путиков О.Ф. Механизмы формирования наложенных ореолов, фиксируемых геоэлектрохимическими и атмохимическими методами // Российский геофизический журнал. 2009. № 47-48. С. 33-50.

\section{МАТЕМАТИЧЕСКОЕ МОДЕЛИРОВАНИЕ ПРИРОДНЫХ И ХИМИКО-ТЕХНОЛОГИЧЕСКИХ СИСТЕМ}

Каржавин В.К.

https://doi.org/10.31241/MIEN.2018.14.22

Геологический институт КНЦ РАН, Апатиты, karzhavin@geoksc.apatity.ru

\section{Аннотация}

Моделирование на ЭВМ служит не просто способом наглядного и достоверного отображения фактических данных, но и является инструментом получения новой информации. На этом фоне проявляются основные тенденции физикохимического моделирования природных и химико-технологических систем. Каждая исследуемая система должна иметь реальные границы термодинамических параметров и определяться тем необходимым и достаточным набором независимых компонентов, с помощью которых можно моделировать всё многообразие природного процесса или переработки минерального сырья. Основой таких исследований является чёткое формулирование и грамотная постановка задачи моделирования, корректный выбор математической модели и т.д.

\section{Ключевые слова}

Математическое моделирование, минимизации свободной энергии Гиббса, термобарометрия, минеральное сырьё, метод равновесные условия, система, давление, температура.

Интенсивное развитие математических дисциплин последних десятилетий способствовали существенному влиянию и воздействию на другие науки. Это, в свою очередь, позволило значительно расширить возможности и повысить эффективность проводимых научных исследований. Математи- 